\title{
What Happened in the Sahara? A Transition over the Bound of Semi-consciousness in Paul Bowles' The Sheltering Sky
}

\author{
Sina Movaghati \\ Kharazmi University of Tehran, Iran \\ E-mail: sinamovaghati@yahoo.com
}

Received: 04-12-2016

Published: 01-05-2017
Accepted: 29-01-2017

doi:10.7575/aiac.ijalel.v.6n.3p.234
Advance Access Published: March 2017

URL: http://dx.doi.org/10.7575/aiac.ijalel.v.6n.3p.234

\begin{abstract}
Paul Bowles' prodigious novel, The Sheltering Sky, is an epitome of a narrative about the Modern Man and his existentialistic dilemmas. After six decades from its initial publication, The Sheltering Sky, still, attracts multitudinous attention for its esoteric and abstruse nature of the occurrences. In regard to nomadic-diasporic lifestyle of the author, and his protagonists, normally, many critical approaches to the text have shifted toward hyper-textual perusals. By mentioning the noteworthy scholarly works which have been done hitherto, this article tries to be faithful to the text as much as possible, and elucidates the myth that, what has really happened in the Sahara which coerced the protagonists to forget their identities to this great extent; thus, hectic and deranged, divagating in the desert, inclining toward the destruction of their identities. In this article, in regard to textual substantiations, 'Sand' and 'Time' are adduced as the two crucial elements which balance two main protagonists' state of semi-consciousness, in the inside journey of self. Also, the concept of 'humanistic identity,' from Bowles' viewpoint, in connexion to the setting of the novel, will be discussed.
\end{abstract}

Keywords: Paul Bowles, The Sheltering Sky, Semi-consciousness, Identity, Nature

\section{Introduction}

Upon reading Paul Bowles' outrageous novel, The Sheltering Sky, the cogitation of Caspar David Friedrich's unparalleled painting, Der Wanderer über dem Nebelmeer, ${ }^{1}$ came and lingered on my mind incessantly. Although, I tried to abstain myself from the exorbitant labeling of artistic and literary works, I couldn't easily disregard the "existential crisis," which can be found in both works. Themes like "alienation, the loss of sustaining religious beliefs, the sense of anxiety and guilt, the growing conviction that life is, at bottom, meaningless" (Quinn 152) etc. tolled in my head like a ceaseless and rampant bell. Perhaps the analogy of Bowles and Friedrich, with each other, is a little bit out of logic and slightly fanciful, but the story of the three sisters, who wanted to drink tea in Sahara, has compelled me to reminisce the painting which $\mathrm{I}$, personally, commend with profuse fondness.

Similar to Friedrich's wanderer, Outka, Mimouna and Aïcha are standing on the top of the hill; and all three-or it's better to say, all four-become perplexed and bewildered in a vis-à-vis with the immense nature which they are confronting. The three sisters melt in the ardor of reunion with Targui ${ }^{2}$ and pass beyond the veil, on the high of the dune; and in lieu of tea, sand embraces their glasses. It strikes me, all the four characters can never reach the things which they see and desire. Friedrich's $19^{\text {th }}$ century painting is mystic and opaque; the landscape detaches itself from the $18^{\text {th }}$ century's "Nature," which was viewed in Age of Enlightenment as something "orderly and benign ... which conflict, disaster, and passion scarcely existed" (Wilson and Reill 416). Besides, it seems that no sense of unification exists between the wanderer and Nature. Kindred to the painting, Bowles' Nature is, also, a "neutral-malevolent" which "is prepared to destroy those who are out of tune with" it (Evans 45). However, if Friedrich's $19^{\text {th }}$ century work of art foreshadows a vague and fogbound future, Bowles' $20^{\text {th }}$ century novel announces numerous wars, colonization, destruction in the name of liberation, and above all, self-centeredness of mankind; in a place where all meanings fade away, and man, who thinks he has the power to conquer his very own existence, outweighs his logic over everything else, and in result, feels no approbation and respect for the Nature which surrounds him. This is the sort of atmosphere at the time of Port's arrival in post-war, colonized North Africa, and the impact of this self-centered logic can be traced in chapter four, when "Port crushes large insects under his feet," and then his endogenous utterance reflects: "I'm in a bad way and so what?"3 (The Sheltering Sky 16)

\footnotetext{
${ }^{1}$ Wanderer above the Sea of Fog; an oil painting composed in 1818.

2 An Arabian male traveler, who usually travels during night.

${ }^{3}$ From exegesis perspective, there can be at least three rational implications from Port's inward utterance: 1- It can simply mean that he lost track of his course. 2- Second implication can refer to the ill-natured act of crushing the insects. 3- On deeper level, "bad way" implies the act of infidelity which soon Port is going to do. In any case, "so what?" denotes the loose and unrestrained conscience of the protagonist.
} 
This self-centered logic is not so distant from the morality; however, this moralization "appears to emanate from the very core of an individual, as that individual confronts and opposes socially inculcated systems of value" (Armstrong 27). Indeed, what assimilates modern novels' heroes with Friedrich's wanderer is the substantial fact that modern hero is disparate from the environment that he inhabits. The conflict of modern fiction is formed in this way because not only the hero does not have an acceptable and universal character, but also he occasionally steps in the deviant routes of life, and challenges the basis and fundament of the issues which has been taken as the irrefutable realities for many generations. (and what technique can be more gratifying than the stream of consciousness to aid the novelist to enact his idea of modern conflict?) In this regard, The Sheltering Sky has succeeded to become the accurate embodiment of the Modern Hero's conflict, as it has been acknowledged for "its ability to show the development of the individual in the modern world" (Reese, "Verbal Violence" 87). It should be taken into deliberation that the discussion on the noteworthiness of the hero in modern fiction cannot be drastically focused on one sole character. Chiefly in TSS, all the pivotal characters form a unity jointly. For instance, Wayne Pounds claims that "Tunner and Kit are phases of Port's self, the one purely physical, the other (Kit, Port's wife) atavistic" (428).

Until now, no major period in the history of fiction-writing had the power to overthrow the supremacy of modern fiction; the glorious history of fiction will continue to revolve around modern hero which is a cloistered and avant-garde misfit. Jay Gatsby, Holden Caulfield, Professor Humbert Humbert, Leopold Bloom, Atticus Finch and others, all and all, see themselves as the restrained captives of the societies which do not have parallel values with them; however, they, somehow, are compelled to adapt themselves to the social norms. But what differentiates Bowles and his heroes from the other akin figures of this category is the self-exiling and nomadic lifestyle that they chose. As Syrine C. Hout puts it: "in fact, the protagonists 'desert' their morally deficient cultures in pursuit of a purer and richer life that they believe they 'deserve' to have or, at least, to explore" (114). It should be noted that even though the spoor of "clash of cultures' is always traced as the prevalent theme of Bowles' narratives, such theme never viewed as the momentous core of his fiction. Wendy Lesser, who notices an authorship and alteration in Bowles' works, asserts that prior to Bowles, writers such as Henry James, D. H. Lawrence and E. M. Forster had exploited the same topic and theme; and if "for James, the distinguishing element" of the cultures "was money or class; for Lawrence, it was virility; and for Forster," it was "faith ... for Bowles the touchstone" was "violence" (402). Although this article does not attempt to pry on other aspects of Bowles' works rather than 'consciousness,' but I indulged myself to bring to reader's attention two most salient features and innovations of Bowles' narratives. As mentioned earlier, the first one was the interwoven nature of Bowles' characters. And the second one is, his touchstone to segregate the two encountering cultures.

Also, to this day, each distinct standpoint could not repudiate the heavy presence of 'barren lands' in Bowles' fiction. As divergent critics with varying approaches, directly or indirectly, referred to 'desert' as an inseparable internode in Bowles' texts. One of the radical assertion belongs to Timothy Weiss, who believes Bowles exploits the African scenery as a muse to himself. Weiss writes: "Bowles drew inspiration from the terrains (cityscapes, landscapes), ... They were to him a muse of sorts" (38). Prior to Weiss, many had relinquished the literal 'desert' of the narrative, and reiterated on the metaphorical 'desert' of self; critics believed that Bowles' characters should be viewed as "expatriates manqué, individuals who inhabit alien terrains of self" (Olson 336). As in TSS, Port and Kit accept "destiny by going into the desolate self and having tea in the Sahara" (Shir 73), therefore 'desert' becomes "a metaphor for the characters' barren psychological landscapes" (Weik von Mossner 220). In fact, it seems that all critics have a consensus that 'barren lands' play metaphorical roles in Bowles' narratives which forge heavy linkages with psychological issues of the characters. In this regard, I want to have a closer inspection of the text, in respect to the 'consciousness' of the characters.

Perhaps one of the overriding reasons for the popularity of TSS arises from the fact that it conforms "to popular expectations of an adventure story, to the extent that it could be recuperated within ... popular generic framework, and thus easily consumed" (Reese, "My Work" 11). The novel narrates the escapade of three middle-aged Americans, who leave the motherland, and arrive at post-war North African terrains. Port and Kit Moresby, along with their friend Tunner, neglect the serene and cultivated European regions for the unrefined and unmapped African enclaves; therefore, the displacement of the protagonists "from the civil world and encompassment by the desert world" becomes "the central motif of The Sheltering Sky" (Hilfer 272). After the outbreak of a contagious disease, Port's health deteriorates and he eventually reposes in the depths of the Sahara. Dejected and deranged, Kit (Port's wife) heads off into the interminable wasteland and becomes a mistress to a young Arab merchant called Belqassim.

\section{The Idiosyncratic Attributions of Time and Sand}

The tale of the three sisters on the top of the dune, which hitherto mentioned, not only "foreshadows Kit's experience later in the book, it also functions as an allegory for the entire novel," (Alarcón 37) as it "epitomises the travel from inside to outside and reflects in miniature The Sheltering Sky's overall plot" (Benlemlih 115). Two distinctive components have moulded this particular exemplum. The first is 'Time,' as it constrains the three sisters to seize the day and travel in favor of the long-repressed predilection; ergo, they savvy that they "must go anyway, even without money" (TSS 30). The subsequent one is the terrene feature (which 'sand' is the most paradigmatic exemplification of this kind), as it is nothing but terra firma in their path to the quiescent demise. 'Time,' and awareness of its passage, can be discerned as a cardinal element which harnesses human consciousness to locate or define its very own existence in materialistic world. However, it can be eyed in TSS that the more the protagonists advance towards the depths of

${ }^{4}$ Henceforth, The Sheltering Sky would be abbreviated as TSS. 
Sahara, time indicators become less efficacious. The indicators are either damaged or mislaid. For instance, in chapter five, when Port stays in Marhnia's tent, it appears that his watch cannot pinpoint the proper time: "he looked anxiously at his watch; it had stopped at five minutes of two. But it was still going. Surely it must be later than that;" (TSS 29) or in chapter twenty-four, after Kit "bathed lengthily" in garden's pool, this thought came to her that she "shall never be hysterical again." And in that state of euphoria, she was not "conscious of the cessation of the drums." Afterwards when "she bent to take her wrist watch from the stone where she had laid it. It was not there;" hence, "she could not verify the hour" (TSS 241-242). Marcellette Williams even views 'Sky' as a symbol for the concept of 'Time,' and asserts that "the sky itself is a symbol for the limit of one's existence, Time. At the moment of Port's death his semiconsciousness pierces the delicate fabric of the sheltering sky and takes repose" (419). Moreover, based on the inferences from chapter twenty-four, it seems that if an individual can get rid of the cognizance about the passage of time, or the finite quiddity of existence, the individual can cross the bound of semi-consciousness and set foot on the realm of non-being or nonexistence which is homologue to the realm of unconsciousness. In chapter twenty-four Port and author's voices mingle in this averment that "death is always on the way, but the fact that you don't know when it will arrive seems to take away from the finiteness of life," and this shapes our notion which results in view "of life as an inexhaustible well" and thence, to us, life appears to become "limitless" (TSS 232). In fact, the yearning to grasp this 'limitlessness' forms the protagonists' destinies, as in the end "Port achieves the non-being of death, while Kit gives herself up to a state of nonbeing ruled over by Eros" (Spindler 39).

In binary modus operandi of ratiocination, we have to mull over on what is implemented as a representative of unconsciousness in the narrative; the answer can be found in Bowles' grains (sand) of unconsciousness, which are exploited as an emblem for the state of lethargy, delirium and unconsciousness. As an instance, in chapter twenty-four when Kit and Tunner slide into the moonlit cup of sand, Tunner shakes Kit's arm "as one does to awaken a person from a deep sleep" (TSS 228). Perhaps Bowles found his emblem of unconsciousness in grains of sand because "each grain of sand sent out a fragment of the polar light shed from above (TSS 227) and for sure, above the limit of sky is 'timelessness' and 'limitlessness.' Not to mention, unlike Port, Kit is not willing to easily let go of her western-civilized consciousness and amalgamate with the realm of unconsciousness; therefore, now and then in the narrative, Kit stops "to shake sand from her shoe" (TSS 123). Another instance of this disinclination can be found in chapter twenty-three when "the cold sand filled" Kit and Tunner's "shoes: they took" the shoes "off and continued" (TSS 227). As a matter of fact, Kit's evasion of sand and her avoidance of involvement, becomes an insignia of her resistance for joining the realm of unconsciousness. It is the same resistant power that in chapter nineteen forces Kit to 'look at her things:' "I felt I'd simply die if I didn't see something civilized soon" (TSS 155). In this respect, in most part of the journey Kit is walking on the thin line of semi-consciousness. Even she withstands the powerful sandstorm in chapter twenty-two which onslaughts their room in a military fort in Sba; Sand enfolds everything inside the room and this acts as an exordium to Port's quietus, but again Kit, who is not psyched up to experience limitlessness, resists and outlasts the sands of unconsciousness:

She arose and moved about the room stiffly in the cold, trying to raise as little dust as possible while she made her toilet. But the dust lay thick on everything. She was conscious of a defect in her functioning-it was as if an entire section of her mind were numb. She felt the lack there: an enormous blind spot inside her-but she could not locate it. And as if from a distance she watched the fumbling gestures her hands made as they came in contact with the objects and the garments. "This has got to stop," she said to herself. "This has got to stop." But she did not know quite what she meant. Nothing could stop; everything always went on. (TSS 202)

As Port and Kit roam "across the Sahara, suffering paroxysms now and then of lust or hatred," they see "chiefly the anonymous sand" (Sutcliffe 731). Moreover, protagonists' tumultuous and topsy-turvical progress in the desert, is synchronized with the bereftness of consciousness, identity and civilization. It should be taken into consideration that the state of lethargy and inertia (timelessness), which is ascribed to a cannabis house in chapter seventeen (TSS 133), is equipollent to Kit's experience of 'timelessness,' which happens in chapter twenty-four, after Port's death: "These were the first moments of a new existence, a strange one in which she already glimpsed the element of timelessness that would surround her" (TSS 231). Thus, as the setting develops to find itself in exotic and far-flung frames, the narrative grows to become a far-fetched, hashish-like hallucination; an American dies in Sahara, in the midst of the twentieth century, and his wife spend most of her time sleeping in stuffy, caliginous chamber of an Arab merchant. Kit's siesta also plays its own momentousness to her state of unconsciousness, and as Marcellette Williams puts it: "In the last section of The Sheltering Sky Kit spends most of her time asleep in Belqassim's windowless room. She" does not use sleep to "refresh and restore" herself "for the following day but rather as a means of remaining mindlessly content in Belqassim's absence" (415). Still, when the sands of unconsciousness accumulated, the concave-convex dunes appear in Sahara. And the act of moving upward and downward from each dune, creates a form of lullaby for each cameleer; the same thing happens to Kit in chapter twenty-six, after she is picked up by Belqassim's caravan. Bowles' description of the ride in the Sahara and his delineation of observing a palm tree during the ride, solely, indicates the delusional mirage of traveler's eyes:

At the hour when the sun shone its hottest, they came within sight of an oasis. The dunes here leveled off to make the terrain nearly flat. In a landscape made gray by too much light, the few hundred palms at first were no more than a line of darker gray at the horizon - a line which varied in thickness as the eye beheld it, moving like a slow-running liquid: a wide band, a long gray cliff, nothing at all, then once more the thin penciled 
border between the earth and the sky ... Soon a solitary thing detached itself from the undecided mass on the horizon, rising suddenly like a djinn into the air. A moment later it subsided, shortened, was merely a distant palm standing quite still on the edge of the oasis. (TSS 264-265)

As the upshot of the above mentioned interactions, 'Time' and 'Sand' equipoise the states of consciousness and unconsciousness of the narrative; this fabricates a state of semi-consciousness for Port and Kit (which is the Prevalent state through the major parts of the novel). But we have to bear in mind that the exertion of trespassing the bound of semi-consciousness to the realm of unknown, has diverse repercussions for each protagonist, and that is why Linda Wagner comes to this asseveration that "Port's death balanced against Kit's action and sexuality" (17).

If the physical insurgency of Kit is aligned to Port's demise, this is because of the fact that physical and materialistic aspects of the narrative are accredited to Kit, and spiritual or non-materialistic aspects are attributed to Port. In chapter two, Port recounts his vision and dream (more of a nightmare) to Kit and Tunner; and again in chapter fifteen, while he was dreaming in his sleep, he suddenly wakes up and only recalls that "The soul is the weariest part of the body" (TSS 118). But unlike Port, Kit is prowling all the time; she follows this 'hysterical' attitude towards everything which is unknown for her, and this attitude of hers has a more vivid appearance in the inceptive chapters of the novel. She gets hysterical in the hotel room, or on the train to Boussif. She also has this puerile materialistic attitude toward people; for example, when he sees the face of an Arab "for no reason she" thinks "of a lion's muzzle" (TSS 78). As a matter of fact, the Saharan sands of unconsciousness summon both Port and Kit into the realm of 'non-being' in accordance to the definition of each character. Port, who has spiritual characteristics, undergoes a 'non-being' entity and peregrinates to the infinity above the sheltering sky; and Kit, who has physical characteristics, becomes unconscious of her body, and therefore, capitulates herself to whomever she finds along the way. "It is at this point that Kit gives into the madness which has been lurking in the back of her mind since their arrival on the continent, and she vanishes from the world" (Martino 93). The process of Kit's yielding her physical entity to Saharan sands can be observed in chapter twenty-six, where she often finds "herself washing in full view of the entire camp, because there" is "nothing behind which she" can "conceal herself" (TSS 271). This nonchalant attitude about her somatic facet is drastically opposed to her behavior at the time of their arrival in North Africa; for example, in chapter six when Tunner knocked on her door, she suddenly became "frantic," and "began to look about the room for the right bathrobe" (TSS 39) before confronting Tunner. Other noticeable instances of Kit paying attention to her somatic beauty, in early stages of the novel, can be found in chapter three where she is "sitting by the open window filling her nails" (TSS 13), or in chapter eight, where she broaches to Tunner that she has to "go ... and find a beauty parlor" (TSS 58). So it can be observed that both Port and Kit trespass the bound of semi-consciousness in their own way and in accordance to their own definitions; 'Time' and 'sand' act as the apparatuses which controls characters' state of consciousness and unconsciousness, respectively.

\section{Identity and the Origin of Travel}

From the beginning of TSS, Bowles mentions Port's mapping of the geographical journey in North Africa; in fact, this geographical journey evokes the metaphorical journey of self. But if we consider the outside and inside journey as coequals, Then, exclusive attention should be paid to geographical or the natural environment (Sahara) of North Africa. Brian Edwards, in his riveting reading of TSS arrives at the illation that there are other engrossing triangles rather than the love triangle between Port, Kit and Tunner; his reading puts emphasis on the role of Sahara as protagonist (or antagonist) of the novel. Edwards writes:

The Sheltering Sky depicts three Americans in their thirties-Port and Kit Moresby and their friend Tunner. In this love triangle in the desert, the secondary triangles are especially compelling: Port, Kit, and the Sahara; errant Americans, stir-crazy French colonials, colonized Algerians. Port and Kit are fleeing the decadence of the West, attempting to escape the incursion of what the novel calls "the mechanistic age". They are also attempting to bridge a gap in their marriage. To do both, they travel further and further "in" to the Sahara, ditching Tunner. (With his "Paramount" good looks ... Tunner stands in for the America they have left behind; he also has seduced Kit.) (315)

In his definition of the narratives' triangles, Brian Edwards actually personifies Sahara as a protagonist (or antagonist of the novel). This personification is exceedingly stimulating, because as Oliver Evans contends: "in a typical Bowles story, a civilized individual comes in contact with an alien environment and is defeated by it" (44). In this respect, not only the nature should be viewed as a sentient entity, but also it should be considered as a prevailing force, which can easily dominate other entities. As some critics reckon, in sooth, there is a close interconnection between natural environments and human's identity because "the natural environment is always a shaping force of individual and group psychology and identity-and that this force can only be ignored or suppressed at a price" (Armbruster and Wallace 7). In fact, the 'price' that Armbruster and Wallace venture to moot, can be addressed as the deprivation and impoverishment of individual's identity in TSS; the humanistic identity, is the entity which lingers with us from the very moment of our birth, and from that point, we constantly annex the mundane appendages of the temporal world to it, and in truth, we expound our existence around the pivot of our identity until the day of our demise. The origin of travel-at least for Port-is the unification with his 'ancestors;' in this way, instead of traveling to modern regions, he progresses into the undeveloped territories of the world; and in the way to his spiritual purification-or unification with nature-he balks himself from any kind of identity-like labeling. For example, in chapter twenty-two, the author reveals that at the 
time of their "disembarkation" in North Africa, Port left "a blank after the word profession on their papers as he had done in his passport" (TSS 192-193). Or in chapter twelve, he elucidates on how he does not entail to carry a passport in order to corroborate he has a right to live:

I don't have to justify my existence by any such primitive means. The fact that I breathe is my Justification. If humanity doesn't consider that a justification, it can do what it likes to me. I'm not going to carry a passport to existence around with me, to prove I have the right to be here! I'm here! I'm in the world! But my world's not humanity's world. It's the world as I see it. (TSS 88-89)

Regarding the concept of identity, the story gets to the enthralling point when Port's passport is purloined by Eric Lyle; because "this taking of Port's identity comes at the" pivotal "point where he is making his final plunge into the interior" (Campbell 142). As in chapter twenty, Port procure this self-awareness "that it rather suited his fancy to be going off with no proof of his identity to a hidden desert town about which no one could tell him anything" (TSS 163). Even the sarcastic lash of Bowles at the conception of 'identity' and the interpretation of Modern existence-at least to me-gets more thought-provoking when the nature of Port's disease kept hidden from the reader. Many critics and reviewers opined that Port was suffered from typhoid, but firmly enunciating, actually there is no point in the story that the nature of Port's malady is specified altogether; we just know that it is a contagious disease, but where and when and how it conceived remain a mystery. Therefore, metaphorically, maybe Port prepensely divests himself of his own identity, and then unconsciously, travels through 'the sheltering sky;' because, veritably, Port preferred the anonymous, nomadicdiasporic way of living over the modern, well-off and insouciant western lifestyle; so when he had the chance, he embraced his fate and voyages to the sky. In contrast to Port, Tunner is a kind of American who actually thinks of Arabs as an inferior race, and hence he resists the idea of existing without any certificate of his existence, and as a result, he does not yield to live unconscious and identity-less in North Africa. Thus, it can be presumed that Port and Tunner's 'infrastructures' are heterogeneous. As Suver puts it: "It is ironic that Tunner was brought along by Port since Port spends most of the novel trying to ditch him in the way he tries to leave behind his American identity. It's therefore appropriate that Tunner is portrayed as very much the typical American" (30). And it should be noted that Tunner is the person who retrieves the stolen passports.

"Throughout this novel there is a constant, if misguided, desire in both Port and Kit to find some kind of wholeness in life," (Summerville 309-310) therefore, unlike Tunner, Bowles' spellbinding game of identity follows a homogeneous procedure for Kit as well as Port. Kit, who bears the physical entity of the narrative-as discussed above-is forced by Belqassim to revamp her attire, and dress as an African boy; hence, rather than a fixed identity, she experiences a mutated one. In addition to undergoing manhood in disguise, Kit, whose quondam marriage was a deceptive monogamy, is subjected to a polygamous marriage, not in a sense of practicing the lifestyle, but in a sense that her character gradually develops to accept the fact of being one of Belqassim's doxies. The veiled and astounding state of identity, in the narrative, is not only incarcerated to Port and Kit. Even we, as the spectators of these cataclysmic events, cannot find out the nature of relationship between Eric Lyle and his mother. Shockingly, at the end of Book One, Mohammed, the hotelkeeper in Aïn Krorfa, insists that he has seen Eric and Mrs. Lyle in bed together: "I opened the door of room eleven, and there they are in the bed. Naturally. You believed him when he said she was his mother? ... You should have seen what I saw ... Then you would know what a liar he was!" (TSS 137) While we are struggling to analyze and substantiate the new information about the Lyles, Port apprises Kit of Mohammed's discovery, and Kit, without surprise, avers "her story of having seen" the Lyles' "passports, so that there was no doubt of their being mother and son" (TSS 157). On the other hand, in a hyper-textual conjecture, the reader has already realized that Eric is a passport thief, and in consequence, it can be a highly unerring supposition that the so called Lyles, are roaming in North Africa with fake Ids, and whenever they are in need of money, they pilfer one or two things in order to subsist. Thus, it is not reliable to consider them as mere tourists and travelogue writers. But if the case is incest or otherwise, one thing can be asserted for certain, that nothing is certain-at least in Bowles' view-regarding a human's identity in the austere environment of the Sahara.

Bowles puts this query in front of us that what is really the 'human identity' or 'human relations' and, above all, what is the nucleus of 'human identity?' And what would happen if 'human' becomes devoid and unconscious of its own identity? For the prevention from sheer loitering on the subject, perhaps this focal passage from the dénouement of the novel can pave the way for further discussions. Kit, who has been, probably, wandering in the French's colonized regions, now is captured and held in the custody of the French. For a few brief junctures, Bowles unlatches the gate of Kit's consciousness, and allots what is happening in her mind:

She knew that the constant references to her closed eyes were being made only in order to trap her into protesting: "But my eyes are open." Then they would say: "Ah, your eyes are open, are they? Then-look!" and there she would be, defenseless before the awful image of herself, and the pain would begin. (TSS 304)

In divers places, Kit looks in the mirror, and whenever she does not find one, she utilizes the small hand mirror in her valise, in order to see herself. But, indeed, what happened in the dénouement of the novel that Kit is this terrified to open her eyes and look at herself? Kit-who traversed both phases of consciousness, and semi-consciousness, and become denuded of her identity-comes to this discernment that there is not going to be a hope for the farcical and preposterous appellation of 'humanity,' as she fathoms that nothing but horror is lurking beyond the veil of 'the 
sheltering sky.' Because the knowledge she gained, propels her to come to this recognition that "everyone is isolated from everyone else." and "the concept of society is like a cushion to protect us from the knowledge of that isolation." Therefore, the whole concept of 'humanity' and 'civilization' is "a fiction that serves as an anesthetic" (Bailey). Plus, the route to Kit's awareness is catalyzed by the ubiquitous presence of nature and natural elements; and in this respect, "Bowles's desert becomes-like Conrad's jungle and Eliot's wasteland-a symbolic landscape, emblematic of a world in which individuals are radically isolated from one another (McInerney 188). As Bowles, himself, puts it: "The transportation of characters to such settings often acts as a catalyst or a detonator" (Bailey).

The stark and astringent setting of the desert reduces both Port and Kit to their most fundamental desideratums; when Port stops 'being human,' he becomes only 'a cloaca' for 'chemical processes:'

The quietness of his dialogue made more monstrous the groans of pain which an instant later issued from within him. "What is it?" she cried in a frenzy. But he could not hear her. She knelt on her mattress and looked at him, unable to decide what to do. Little by little he grew silent, but he did not open his eyes. For a while she studied the inert body as it lay there beneath the covers, which rose and fell slightly with the rapid respiration. "He's stopped being human," she said to herself. Illness reduces man to his basic state: a cloaca in which the chemical processes continue. The meaningless hegemony of the involuntary. It was the ultimate taboo stretched out there beside her, helpless and terrifying beyond all reason. (TSS 208)

In Sanford Pinkser's words, Kit goes beyond her husband's experience and "becomes the automaton extraordinaire that" Port, "despite his self-conscious efforts, could not achieve. If Port imagines some existential truth, some liberating reality" which the "civilization has suppressed, Kit realizes all too clearly that she is 'in the middle of horror.' Hers is the 'perfect knowledge' that there is no hope-not even of the sort Port clings to" (8). The description of Kit's shelterless condition in chapter twenty-one is the quintessence of what happened to Kit in the Sahara:

She stopped, with the sensation that she was about to faint. She was shaking with fatigue, and her mouth and throat felt as though they were made of tin. The sun poured down on the bare earth; there was not a square inch of shadow, save at their feet. Her mind went back to the many times when, as a child, she had held a reading glass over some hapless insect, following it along the ground in its frenzied attempts to escape the increasingly accurate focusing of the lens, until finally she touched it with the blinding pinpoint of light, when as if by magic it ceased running, and she watched it slowly wither and begin to smoke. She felt that if she looked up she would find the sun grown to monstrous proportions. (TSS 185)

The fact that now Kit sees herself as a mere insect has a vigorous incongruity with what we see in the opening chapters of the narrative-which hitherto discussed-when 'Port crushes large insects under his feet.' Parallel to Port's basic state of 'chemical processes,' Kit is reduced to be a mere animal: "It was so long since she had canalized her thoughts by speaking aloud, and she had grown accustomed to acting without the consciousness of being in the act. She did only the things she found herself already doing" (TSS 270). This description from Book Three, connotes that Kit is engaged in an animalistic-instinctual activity, which leaves no room for internal consciousness. From this point, 'onward,' actually her attitude towards living, more associates with an animalistic way of existence rather than the humanistic traits. The encaged Kit in chapter twenty-seven, 'screams' as she feels "the soft features of the face beneath her clenched finger." She tries to "rip the thing to shreds." She also bites "into soft flesh" and clamps "her jaws." "the sensation" is "delicious," as she tastes "the warm salt blood on her tongue" (TSS 282). This account of Kit's scrimmage with Belqassim's wives is homologous to her other concatenation of action in Book Third. In most part of Book Third, we see her only eating, drinking, sleeping and, above all, satisfying the needs and pleasures of her dominator(s); As "the identity of others has ceased to have any meaning for Kit except in their ability to dominate her, because she can define herself only in the experience of being dominated" (Wolff xii).

A gargantuan portion of the omnipresent, animalistic traits are embedded in Book Three; therefore, it would be lucrative to look at the three divisions of the novel in accordance to the subject of our discussion. Even the tripartite structure of the plot, also, instigates this hypothesis that all of the narrative functions as the inner journey of self; as Book One, "Tea in the Sahara," hints at the ardor for the inception of the journey, Book Two, "The Earth's Sharp Edge," insinuate at the sharp and tenuous edge of semi-consciousness, where the protagonists are going to 'pierce the fine fabric of the sheltering sky;' and, as a result, transit from the border of semi-consciousness to the realm of unconsciousness and, therefore, ascend to "the sky," which is the title of Book Three. Furthermore, many natural traits, like 'sun' and 'desert,' expedite this quest of self; as it is noticeable in chapter nineteen, Port's faculty of consciousness (or it is better to say his typical consciousness of a Modern Man) is shown as a contrasting element with the natural elements of the desert:

The landscape was there, and more than ever he felt he could not reach it. The rocks and the sky were everywhere, ready to absolve him, but as always he carried the obstacle within him. He would have said that as he looked at them, the rocks and the sky ceased being themselves, that in the act of passing into his consciousness, they became impure. (TSS 162)

The above mentioned explicative passage, reveals its significance when, one chapter later, lieutenant d'Armanac, the commander of the military post in Bou Noura, tells Port "the sun is a great purifier" (TSS 166) and no impurity can be 
safe from its scorching heat. As the landscape 'purifies' the protagonists (and their transitions get complete), it can be observed in the opening of chapter twenty-eight that Kit, who is in fathomless sleep, experiences a trancelike stupor in her reverie: "She lay on the narrow shelf of rock, face down, head hanging over, watching the slow waves moving inward from far out there where the curving horizon rose toward the sky" (TSS 293). She finally 'let go' and wakes up afterwards. Consequently, her collapse can be described as the paradoxical plunge to the sky (Kit's plunge is also parallel with Port's paradoxically necrotic catharsis). Indeed, the austere and dour properties of the Sahara put it in such an environmental level where nothing can be seen but earth, sand, and sky; ergo, the passage of time-which is the foremost factor for locating our consciousness in universe-cannot be traced in the sense which is perceived by the modern man. Therefore, "the natural world in The Sheltering Sky" becomes "a dark lurking force that drives Port and Kit deep into death and dissolution ... The ecology of this natural world is one of the loss of civilized notions" (Marques 288).

\section{Concluding Remarks}

The protagonists of TSS, like their author, are the outcasts of the motherland. But what, in the first place, involve the mind to itself is the nature of this banishment and exile. It seems to me that the 'Modern Man,' with a self-expulsion from the initial community, takes distance from the modern society and modern longings, and walks toward a remote place, in pursuit of the lost identity and his unknown 'ancestors.' As Tennessee Williams, in his renowned review of TSS, “An Allegory of Man and His Sahara,” writes:

"The Sheltering Sky" is the chronicle of such a journey. Were it not for the fact that the chief male character, Port Moresby, succumbs to an epidemic fever during the course of the story, it would not be hard to identify him with Mr. Bowles himself. Like Mr. Bowles, he is a member of the New York intelligentsia who became weary of being such a member and set out to escape it in remote places. Escape it he certainly does. He escapes practically all the appurtenances of civilized modern life. Balanced between fascination and dread, he goes deeper and deeper into this dreamlike "awayness." (326)

In a territory where nothing but sand, sky and earth can prevail, Port is in pursuit of "a very mystical desire for the annihilation of the self' (Almond 312), or purifying his 'identity' as a human. The existentialistic taunt of Bowles to the word 'humanity' becomes so indispensable, that it cannot be easily taken for granted. And if we deduce that the nature of Kit's apprehension from looking at herself in the mirror is congruent with whatever which the characters from the fictions of Conrad, Kafka, Dostoevsky and Camus had seen, we have to accept that The Sheltering Sky walks shoulder to shoulder with the literary giants, thus it should be reckoned as one of the great classics. Port and Kit, who view the world of 'humanity' as a place for the wiles and irenic infidelities-instead of living in it with a distraught conscienceprefer to surrender to their instincts and give up themselves thoroughly to the truculent 'Nature.' And as Hamdaoui notes, both Port and Kit come to different repercussions in their own routes to capitulation:

Bowles gives the reader two distinct versions of what might lie behind the sheltering sky: the void or chaos. Behind Port's sky there was nothing, which meant for him peace and repose. But when Kit glimpses behind the veil, like Conrad's Kurtz, she sees "horror". Instead of Peace, she finds psychic anarchy. (65-66)

It should be noted that the origin of challenging the fundamental and pre-established humanistic mores and social proprieties, is not only limited to Bowles or Modern writers. It can be assumed that Bowles, in challenging the fundamental issues of human beings, was inspired from the writers of the Age of Enlightenment like Diderot and Sterne (not in a satiric mode of confrontation with the issues of 'existence,' but as a realistic look at the surroundings). As the nature of the marital relationship between Port and Kit, evokes the famous fable of "the Sheath and the knife" in Diderot's Jacques the Fatalist. ${ }^{5}$

\footnotetext{
${ }^{5}$ The Famous Fable of "the Sheath and the Knife" derived from pages 97 and 98 of Jacques the Fatalist and His Master. Oxford: Oxford University Press, 1999. Print. Translated from the French source by David Coward:

Jacques. Look here, sir, the lofty thoughts you voiced just now out of the blue are all very well, but they don't compare with an old fable people used to tell in my village on autumn evenings.

Master. What fable was that?

Jacques. The fable of the Sheath and the Knife. One day, the Sheath and the Knife began to quarrel. The Knife said to Sheath: 'Sheath, my love, you are a fickle jade, for every day you accommodate new knives.'

The Sheath answered the Knife: 'Knife, my dear, you are a faithless knave, for every day you change sheaths.'

'Sheath, that is not what you promised me.'

'Knife, you deceived me first.'

This quarrel occurred at table. The man sitting between the Sheath and the Knife spoke up saying:

'You, Sheath, and you, Knife, were both right to change, since change is what suits the both of you. But you were quite wrong to promise that you would not change. Knife, can you not see that God made you to fit more than one Sheath? And you, Sheath, to accommodate more than one Knife? You thought certain knives were mad when they vowed to dispense altogether with sheaths, and you thought certain sheaths mad when they vowed to remain closed to all knives. But you did not think that you were just as mad as they when you, Sheath, swore to limit yourself to one Knife, and you, Knife, never to look beyond on Sheath.'
} 
I should conclude that, in my estimation, with the use of sheer comparison and analysis neither one can praise a literary work nor disesteem it; in fact, it is the 'time' itself which can put its approval seal at a work and be the best judge for proving its grandeur and acceptability. After six decades, which it was initially published, The Sheltering Sky is still one of the best-sellers and most-read amongst the fictions, and this fact puts it in the place of the most valued classics. Also, The Modern Library publishing company considered The Sheltering Sky as one of the 100 best novels of all time. ${ }^{6}$

\section{References}

Alarcón, Daniel Cooper. "Travel Narratives, Travel Fictions: The Prescient Case of Paul Bowles". Arizona Quarterly: A Journal of American Literature, Culture, and Theory 72.1 (2016): 25-50. Print.

Almond, Ian. "Experimenting with Islam: Nietzschean Reflections On Bowles's Araplaina". Philosophy and Literature 28.2 (2004): 309-323. Print.

Armbruster, Karla, and Kathleen R Wallace. Beyond Nature Writing. Charlottesville: University Press of Virginia, 2001. Print.

Armstrong, Nancy. How Novels Think. New York: Columbia University Press, 2005. Print.

Bailey, Jeffrey. "Paris Review - The Art of Fiction No. 67, Paul Bowles". Theparisreview.org. N.p., 2016. Web. 11 Apr. 2016.

Benlemlih, Bouchra. "Inhabiting The Exotic: Paul Bowles and Morocco". Ph.D. University of Nottingham, 2009. Print.

Bowles, Paul. The Sheltering Sky. 65th Anv ed. New York: Ecco, 2014. Print.

Campbell, Neil. "The Unfinished Scream: The Disintegration of the Self and The Society in The Works of Paul Bowles". Ph.D. The University of College of Wales, Aberystwyth, 1987. Print.

Edwards, Brian T. "Sheltering Screens: Paul Bowles and Foreign Relations". American Literary History 17.2 (2005): 307-334. Print.

Evans, Oliver. "Paul Bowles and The "Natural" Man". Critique: Studies in Contemporary Fiction 3.1 (1959): 43-59. Print.

Hamdaoui, Zoubida. "Themes and Story-Telling Strategies in Paul Bowles's North-African Fiction". Ph.D. University of Granada, 2013. Print.

Hilfer, Anthony Channell. "Small Figures in Large Landscapes". Texas Studies in Literature and Language 54.2 (2012): 270-283. Print.

Hout, Syrine C. "Grains of Utopia: The Desert as Literary Oasis in Paul Bowles's The Sheltering Sky and Wilfred Thesiger's Arabian Sands". Utopian Studies 11.2 (2000): 112-136. Print.

Lesser, Wendy. "Murder as Social Impropriety: Paul Bowles's "Evil Heroes"'". Twentieth Century Literature 32.3/4 (1986): 402-407. Print.

Marques, Nuno. "Experiences of Death and Dissolution in Paul Bowles's The Sheltering Sky and Jack Kerouac's Desolation Angels and The Dharma Bums". Paul Bowles - The New Generation: Do You Bowles?. Anabela Duarte. 1st ed. New York: Brill | Rodopi, 2014. 285-289. Print.

Martino, Andrew. "The Vanishing Point: The Dis-Integration of Female Identity In Paul Bowles's "The Sheltering Sky"'. South Atlantic Review 71.2 (2006): 87-114. Print.

McInerney, Jay. "Paul Bowles in Exile." Conversations with Paul Bowles. Ed. Gena Dagel Caponi. Jackson: UP of Mississippi, 1993. 180-92. Print.

Olson, Steven E. "Alien Terrain: Paul Bowles's Filial Landscapes". Twentieth Century Literature 32.3/4 (1986): $334-$ 349. Print.

Pinsker, Sanford. "Post-War Civilization and Its Existential Discontents: Paul Bowles's The Sheltering Sky". Critique: Studies in Contemporary Fiction 27.1 (1985): 3-14. Print.

Pounds, Wayne. "Paul Bowles and Edgar Allan Poe: The Disintegration of the Personality". Twentieth Century Literature 32.3/4 (1986): 424-439. Print.

Quinn, Edward. A Dictionary of Literary and Thematic Terms. New York: Facts On File, 2006. Print.

Reese, Sam. "'My Work Has Nothing to Do with Surrealism': Paul Bowles, View and The Surreal Short Story". Papers of Surrealism Summer.10 (2013): 1-19. Print.

Reese, Sam. "Verbal Violence and Patterns of Words: Poe, Bowles, And an Alternative American Tradition". Poe Studies 43 (2013): 78-93. Print.

Shir, Jay. "The Black Star: Paul Bowles' "The Sheltering Sky"". AAA: Arbeiten aus Anglistik und Amerikanistik 8.1 (1983): 67-78. Print.

6 "100 Best Novels « Modern Library". Visit the webpage: http://www.modernlibrary.com/top-100/100-best-novels/ 
Spindler, Michael. "The Prism of Estrangement: Placing The Fiction of Paul Bowles". Australasian Journal of American Studies 8.1 (1989): 35-45. Print.

Summerville, Chris. "The Desert Within: Searching for Union in Paul Bowles' The Sheltering Sky". 立命館言語文化 研究 23.2 (2011): 307-317. Web. 17 Apr. 2016.

Suver, Stacey A. "A Dream of Tangier: Revolution and Identity in Post-War Expatriate Literature". Ph.D. The Florida State University, 2012. Print.

Sutcliffe, Denham. "Novels of the Nebulous Self". The Kenyon Review 12.4 (1950): 730-734. Print.

Wagner, Linda W. "Paul Bowles and The Characterization of Women". Critique: Studies in Contemporary Fiction 27.1 (1985): 15-24. Print.

Weik von Mossner, A. "Encountering The Sahara: Embodiment, Emotion, And Material Agency in Paul Bowles's The Sheltering Sky". Interdisciplinary Studies in Literature and Environment 20.2 (2013): 219-238. Print.

Weiss, Timothy. "Paul Bowles as Orientalist: Toward a Nomad Discourse." Journal of American Studies of Turkey 7. (1998): 37-61. Print.

Williams, Marcellette G. "'Tea in the Sahara": The Function of Time in the Work of Paul Bowles". Twentieth Century Literature 32.3/4, Paul Bowles Issue (1986): 408-423. Print.

Williams, Tennessee. "An Allegory of Man and His Sahara". The Sheltering Sky. Paul Bowles. 65 ${ }^{\text {th }}$ Anv ed. New York: Ecco, 2014. 324-327. Print.

Wilson, Ellen Judy, and Peter Hanns Reill. Encyclopedia of The Enlightenment. New York: Facts On File, Inc., 2004. Print.

Wolff, Tobias. "The Sheltering Sky: An Introduction". The Sheltering Sky. Paul Bowles. 65 ${ }^{\text {th }}$ Anv ed. New York: Ecco, 2014. Xi-Xvi. Print. 